\title{
ODPOWIEDZIALNOŚĆ ZA SZKODY WYRZĄDZONE PRZEZ ZWIERZĘTA WOLNO ŻYJĄCE W ŚWIETLE OBOWIĄZUJĄCYCH REGULACJI PRAWNYCH I ORZECZENIA TRYBUNAEU KONSTYTUCYJNEGO**
}

\section{LIABILITY FOR DAMAGE CAUSED BY WILD ANIMALS IN LIGHT OF LEGAL REGULATIONS AND THE JUDICIAL DECISION OF THE CONSTITUTIONAL TRIBUNAL ${ }^{* * *}$}

http://dx.doi.org/10.12775/PPOS.2013.015

\section{STRESZCZENIE}

Celem niniejszego artykułu jest zwrócenie uwagi na niejasności prawne i potrzebę zmiany regulacji prawnych dotyczących odpo-

" Magister prawa, radca prawny, doktorantka na Wydziale Prawa i Administracji Uniwersytet Mikołaja Kopernika w Toruniu.

*** Wyrok Trybunału Konstytucyjnego z dnia 3 lipca 2013 roku, sygn. akt P 49/11, nr 73/6/A/2013, Dz.U. poz. 842.

**** Decision of the Constitutional Tribunal of 3 July 2013, P 49/11, nr 73/6/A/2013, Dz.U. poz. 842. 
wiedzialności cywilnej za szkody wyrządzone przez zwierzynę łowną i przez zwierzęta objęte ochroną gatunkową. Artykuł powstał na podstawie tekstów źródłowych, głównie ustawy Prawo łowieckie, ustawy o ochronie przyrody i ustawy o ochronie zwierząt, dokumentacji opisującej problemy osób poszkodowanych, interpelacji poselskich i wniosków kierowanych do organów władzy, a także dokumentacji związanej z wydaniem orzeczenia Trybunału Konstytucyjnego z dnia 3 lipca 2013 roku (P 49/11).

Ustawodawca przewidział szczególne zasady odpowiedzialności za szkody wyrządzone przez niektóre gatunki zwierząt z listy zwierząt łownych i zwierząt objętych ochroną gatunkową. Nadto, możliwość zastosowania tych zasad uzależniona jest od rodzaju mienia, w którym zwierzę wyrządziło szkodę oraz od wielkości szkody. W wyroku wydanym w dniu 3 lipca 2013 roku Trybunał Konstytucyjny uznał, że sprzeczne z Konstytucją są regulacje uzależniające przyznanie odszkodowania w trybie ustawy o ochronie przyrody za szkody wyrządzone przez bobry, od rodzaju mienia, w którym szkoda wystąpiła. W świetle powyższego wyroku oraz w odpowiedzi na postulaty osób poszkodowanych i rozmiar doznawanych szkód pożądana jest zmiana regulacji prawnych rządzących odpowiedzialnością cywilną za szkody wyrządzone przez tę zwierzynę.

\section{Słowa kluczowe}

Zwierzęta chronione, zwierzęta łowne, szkoda, odszkodowanie, Konstytucja

\section{ABSTRACT}

This article aims to present the issue of liability for damage caused by wild animals and to signal the need to amend legal regulations governing civil liability for the damage caused by game and protected species of animals. The paper is based on source texts, mainly the Game Laws Act, the Nature Protection Act and the Animal Protection Act, documentation evidencing problems faced by aggrieved persons, parliamentary interpellations and motions addressed to the authorities, as well as documentation connected with the decision of 3 July 2013 (P 49/11) by the Constitutional Tribunal.

The legislator has provided for special liability rules governing

$3 / 2013$ the liability for the damage caused by certain animal species from the 
list of game and protected species. The possibility of applying these rules depends on the type of damaged property and on the magnitude of that damage. In the decision issued on 3 July 2013 the Constitutional Tribunal declared it unconstitutional that the regulations, under the Nature Protection Act, make the award of compensation conditional on the type of property to which the damage was caused.

In light of the above decision and in response to injured persons' demands and considering the demands of the injured persons and the scale of the damage suffered, it is desirable to change the regulations governing civil liability for damage caused by these animals.

\section{Keywords}

Protected animals, game animals, damage, compensation, Constitution

\section{UWAGI WPROWADZAJĄCE}

Wobec coraz częściej pojawiających się roszczeń odszkodowawczych za szkody wyrządzone przez różnorakie zwierzęta wolno żyjące (zwierzęta dzikie) ${ }^{1}$ określenie zasad tej odpowiedzialności staje się coraz bardziej istotne zarówno dla tych, którzy doznali szkody ze strony tych zwierząt, dla podmiotów zobowiązanych do naprawiania wyrządzonych szkód, jak również dla podmiotów realizujących politykę państwa w zakresie

1 Decision of the Constitutional Tribunal of 3 July 2013, P 49/11, nr 73/6/A/2013, Dz.U. poz. 842. artą w art.4 pkt 21) ustawy o ochronie zwierząt z dnia 21 sierpnia 1997 roku, Dz.U. 2013.856 tj. ze zm., określającą zwierzęta wolno żyjące (zwierzęta dzikie) jako zwierzęta nieudomowione, wolno żyjące w warunkach niezależnych od człowieka. Definicja ta ma, w ocenie autorki, charakter ogólny i dotyczy zarówno regulacji w przedmiocie odpowiedzialności za szkody wyrządzone przez zwierzęta łowne (zawartych w ustawie Prawo łowieckie, która posługuje się pojęciem „zwierzęta łowne, zwierzyna"), jak i regulacji w przedmiocie odpowiedzialności za szkody wyrządzone przez te ze zwierząt wolno żyjących, które zostały objęte ochroną gatunkową (zawartych w ustawie o ochronie przyrody posługującej się pojęciem „zwierzęta dziko występujące, czyli niepochodzące z hodowli bądź wprowadzone do środowiska przyrodniczego w celu odbudowy lub zasilenia populacji”). 
ochrony przyrody. Czy istnieje bowiem właściwa odpowiedź na pytania: dlaczego ustanowiono inne zasady odpowiedzialności za szkody wyrządzone przez kormorany, żurawie i czaple w stawie rybnym i za szkody, jakie niedźwiedzie wyrządzają w pasiekach? Czy odmienne uregulowanie zasad odpowiedzialności za szkody wyrządzone przez dziki w uprawach i płodach rolnych i odpowiedzialności za szkody w innym mieniu lub szkody na osobie jest zgodne z prawem?, czy wreszcie, dlaczego poszkodowany może dochodzić roszczeń w trybie przewidzianym przepisami ustawy Prawo łowieckie i ustawy o ochronie przyrody tylko wtedy, gdy szkoda przekroczyła określoną wysokość?

\section{ODPOWIEDZIALNOŚĆ CYWILNA ZA SZKODY WYRZADDZONE PRZEZ ZWIERZĘTA WOLNO ŻYJĄCE - ZAGADNIENIA OGÓLNE}

Zwierzęta wolno żyjące (zwierzęta dzikie), czyli zgodnie z przepisami ustawy o ochronie zwierząt ${ }^{2}$ zwierzęta nieudomowione, wolno żyjące w warunkach niezależnych od człowieka są dobrem ogólnonarodowym. Nie oznacza to jednak, że Skarb Państwa ponosić będzie jednakową odpowiedzialność za szkody wyrządzone przez wszystkie zwierzęta żyjące w stanie wolnym. Konstytucja nie ustanawia prawa podmiotowego do otrzymania odszkodowania za szkodę wyrządzoną przez zwierzęta dzikie.

W ustawie Prawo łowieckie ${ }^{3}$ oraz w ustawie o ochronie przyrody $^{4}$ ustawodawca dokonał szczególnego uregulowania odpowiedzialności za szkody wyrządzone przez określone gatunki zwierząt łownych oraz zwierząt podlegających ochronie gatunkowej. Jest ono korzystniejsze dla poszkodowanych

2 Ustawa z dnia 21 sierpnia 1997 r. o ochronie zwierząt, t.j. Dz.U. z 2013 r., poz. 856.

3 Ustawa Prawo łowieckie z dnia 13 października 1995 roku, Dz.U.2005.127.1066 tj. ze zm.

4 Ustawa o ochronie przyrody z dnia 16 kwietnia 2004 roku, Dz.U.2013.627 tj. ze zm. 
przede wszystkim dlatego, że jest to odpowiedzialność obiektywna, niezależna od tego, czy zachowanie podmiotu odpowiedzialnego było zgodne z prawem, czy też nie i niezależna od winy podmiotu zobowiązanego do naprawienia szkody.

Podkreślenia jednak wymaga, co znalazło potwierdzenie w przyjętej linii orzeczniczej, że brak szczególnego przepisu o odpowiedzialności Skarbu Państwa za szkody wyrządzone przez zwierzynę łowną, poza regulacjami przewidzianymi w ustawie Prawo łowieckie dla wskazanych w niej gatunków, nie zwalnia Skarbu Państwa od ponoszenia odpowiedzialności na zasadach ogólnych ${ }^{5}$. Podobnie brak w ustawie o ochronie przyrody szczególnego przepisu dotyczącego odpowiedzialności Skarbu Państwa za szkody wyrządzone przez niektóre zwierzęta objęte ochroną gatunkową, nie wyłącza odpowiedzialności Skarbu Państwa na zasadach ogólnych.

Przedmiotem regulacji wymienionych wyżej ustaw jest ochrona środowiska naturalnego realizowana w ramach ochrony gatunkowej zwierząt i gospodarki łowieckiej. Nie ulega przy tym wątpliwości, że zwierzęta te wyrządzają szkody zarówno w „świecie roślin”, jak i w „świecie zwierząt”. Ustawodawca brał pod uwagę możliwą kolizję między wymogami związanymi z ochroną przyrody, a zagrożeniem życia, zdrowia i mienia spowodowanymi aktywnością gatunków podlegających ochro$n^{e^{6}}$. Wynagradzanie takich szkód na szczególnych (korzystniejszych) zasadach należy zatem uznać za jeden z elementów polityki państwa $\mathrm{w}$ zakresie ochrony środowiska. Skoro bowiem w realizację celów związanych z ochroną gatunkową zwierząt i gospodarką łowiecką wpisane są niejako skutki działalności zwierzyny i szkody przez nią wyrządzane, to odpowiedzialność za takie szkody powinna mieć charakter zaostrzony. Z drugiej

5 Wyrok Sądu Najwyższego z dnia 17 czerwca 1966 roku, I CR 360/66, OSNC 1967/2/30 Wyrok Sądu Apelacyjnego w Warszawie z dnia 5 marca 1999 roku, I ACa 1386/98, OSA 2001/3/17 Uchwała Sądu Najwyższego z dnia 7 grudnia 2007 roku, III CZP 120/07, OSNC 2008/12/136.

6 Uzasadnienie wyroku Trybunału Konstytucyjnego z dnia 3 lipca 2013 roku, sygn. akt P 49/11, http://isap.sejm.gov.pl/Download;jsessioni$\mathrm{d}=$ 3DE72522DA4165DDE65CF58BD79BC34C? id=WDU20130000842\&ty$\mathrm{pe}=1$. 
strony, człowiek poszkodowany zachowaniem zwierzęcia, mając świadomość, że doznana szkoda, zostanie naprawiona, nie dąży do zapewnienia sobie rekompensaty na własną rękę, co niejednokrotnie mogłoby prowadzić do działań odwetowych względem zwierzęcia ${ }^{7}$ lub do podejmowania niedozwolonych działań zmierzających do jego odstraszania czy zabijania.

Odpowiedzialność za szkody wyrządzone przez zwierzęta wolno żyjące została ukształtowana przez polskiego ustawodawcę $\mathrm{w}$ niejednolity sposób. Próba określenia zasad rządzących tą odpowiedzialnością rozpoczyna się od analizy ustawy Prawo łowieckie i ustawy o ochronie przyrody.

\section{ZASADY ODPOWIEDZIALNOŚCI ZA SZKODY NA GRUNCIE USTAWY PRAWO ŁOWIECKIE}

Regulacje dotyczące łowiectwa, czyli ochrony zwierząt łownych i gospodarowania ich zasobami w zgodzie z zasadami ekologii oraz zasadami racjonalnej gospodarki rolnej, leśnej i rybackiej zostały ustanowione ustawą Prawo łowieckie. Wśród zwierząt łownych, za które należy uważać 31 gatunków zwierząt znajdujących się na liście określonej w drodze rozporządzenia, rozróżnia się zwierzynę grubą, w tym dzika, jelenia czy sarnę oraz zwierzynę drobną, jak na przykład lisa, kunę czy zająca szaraka. Ustawodawca przewidział, że za szkody wyrządzone przez niektóre ze zwierząt łownych znajdujących się na tej liście, tj. za szkody wyrządzone przez dziki, łosie, jelenie, daniele i sarny odpowiadać będzie dzierżawca lub zarządca obwodu łowieckiego, nawet jeśli dołożył wszelkich możliwych starań w celu niedopuszczenia do powstania szkód ${ }^{8}$. Jeśli zwierzęta te wyrządzą szkodę na obszarach niewchodzących w skład obwodów łowieckich, wówczas odpowiedzialność ponosić będzie Skarb Państwa. Za szkody wyrządzone przez zwierzęta łowne

7 M. Goettel, Sytuacja prawna zwierzęcia $w$ prawie cywilnym, Warszawa 2013, s. 437.

8 W. Radecki, Prawo łowieckie. Komentar\%, Warszawa 2012, s. 288. 
objęte całoroczną ochroną (obecnie jedynym takim zwierzęciem jest łoś) odpowiadać będzie Skarb Państwa, niezależnie od tego, czy szkoda powstała na terenie obwodu łowieckiego, czy też nie. Co istotne, opisana powyżej odpowiedzialność dotyczyć będzie wyłącznie szkód wyrządzonych w uprawach i płodach rolnych, a odszkodowanie nie będzie przysługiwać, jeśli wysokość szkody nie przekroczy wartości 100 kilogramów żyta w przeliczeniu na jeden hektar uprawy.

\section{ZASADY ODPOWIEDZIALNOŚCI ZA SZKODY NA GRUNCIE USTAWY O OCHRONIE PRZYRODY}

Ustawą o ochronie przyrody ustawodawca realizuje zadania polegające na zachowaniu, zrównoważonym użytkowaniu oraz odnawianiu zasobów, tworów i składników przyrody. W tym celu wprowadza się między innymi ochronę gatunkową zwierząt wiążącą się z zakazami chwytania, zabijania, płoszenia, wybierania jaj czy niszczenia ostoi poszczególnych gatunków. Mocą przedmiotowej ustawy ustanowiono odpowiedzialność Skarbu Państwa za szkody wyrządzone przez niektóre ze zwierząt chronionych, tj. za szkody wyrządzone przez żubry, wilki, rysie, niedźwiedzie i bobry, z tym że jest to odpowiedzialność ograniczona do poniesionych strat, a więc nie obejmuje utraconych korzyści. Nadto, odpowiedzialność Skarbu Państwa została ograniczona do szkód wyrządzonych przez żubry w uprawach, płodach rolnych lub w gospodarstwie leśnym; przez wilki i rysie w pogłowiu zwierząt gospodarskich; przez niedźwiedzie w pasiekach, w pogłowiu zwierząt gospodarskich oraz w uprawach rolnych oraz przez bobry w gospodarstwach rolnych, leśnych lub rybackich. Podobnie, jak w ustawie Prawo łowieckie, wśród przesłanek wyłączających prawo do odszkodowania ustanowione zostało również kryterium minimalnej wysokości szkody uprawniającej do odszkodowania, czyli wartości 100 kilogramów żyta w przeliczeniu na jeden hektar uprawy w ciągu roku. Niezależnie od tego ustawodawca przewidział możliwość wydania rozporządzenia rozszerzającego listę gatunków zwierząt 
chronionych wyrządzających szkody, za które odpowiada Skarb Państwa, mając na uwadze potrzebę utrzymania ochrony gatunkowej zwierząt zagrożonych wyginięciem i wyrządzających szkody w gospodarce człowieka.

\section{UŁOMNOŚĆ REGULACJI PRAWNEJ W ZAKRESIE SZKÓD WYRZĄDZONYCH PRZEZ ZWIERZĘTA- UJĘCIE POSTULATYWNE}

Sformułowane w powyższy sposób zasady odpowiedzialności Skarbu Państwa i dzierżawców bądź zarządców kół łowieckich za szkody wyrządzone przez zwierzynę w stanie wolnym budzą wiele wątpliwości, czego najlepszym przykładem są coraz liczniejsze postulaty dotyczące ich zmiany.

Grupą żywotnie zainteresowaną poruszanymi zagadnieniami są przede wszystkim rolnicy i hodowcy ryb, którzy doświadczają szkód wyrządzanych przez zwierzynę. W tym miejscu można wskazać na pojawiające się doniesienia prasowe. Przedstawiane w nich przykłady doznanych szkód wskazują na to, że regulacje prawne nie są $\mathrm{w}$ tym zakresie wystarczające. Członkowie Zachodniopomorskiej Izby Rolniczej informują, że „rolnicy dłużej nie wytrzymają obecnej sytuacji, gdyż szkody spowodowane przez zwierzynę łowną, a także chronioną (żurawie, łabędzie, czaple, kormorany) są coraz większe. Ten problem musi zostać rozwiązany kompleksowo"9. Podniesiony został również postulat, aby odpowiedzialność Skarbu Państwa za szkody wyrządzone przez bobry nie ograniczała się jedynie do szkód w gospodarstwie rolnym, leśnym i rybackim, ponieważ drzewo naruszone przez bobry może spaść komuś na głowę albo uszkodzić ciągnik, a bobry żerują w miejscu, gdzie przeby-

9 Zachodniopomorska Izba Rolnicza, Szkody łowieckie - narastający problem zachodniopomorskich rolników, 5 kwietnia 2013 roku, http://www. archiwum2.zir.pl/index.php/210-szkody-lowieckie-narastajacy-problemzachodniopomorskich-rolnikow. 
wają wędkarze ${ }^{10}$. Z kolei kujawsko-pomorscy rolnicy postulują, aby odszkodowania wypłacane były także za szkody wyrządzone przez łabędzie czy żurawie w oziminach. „Wtedy nie ma co liczyć nawet na odszkodowanie. To niesprawiedliwe!"11. Do Krajowej Rady Izb Rolniczych napływają z wielu województw wnioski dotyczące niszczenia zasiewów i upraw przez zwierzęta objęte ochroną gatunkową, takie jak żurawie, kormorany i gęsi. Rolnicy skarżą się, że zapobieganie tym szkodom jest praktycznie niemożliwe ze względu na ograniczenia związane $\mathrm{z}$ odstraszaniem ptaków objętych ochroną, które w konsekwencji stają się coraz mniej płochliwe i żerują na polach, nie lękając się człowieka $^{12}$.

Problematyka odpowiedzialności za szkody wyrządzone przez zwierzęta wolno żyjące była i nadal jest przedmiotem zainteresowania także ze strony posłów, do których zgłaszają się poszkodowani rolnicy i rybacy. O skali problemu świadczą liczne interpelacje dotyczące zagadnienia wyrządzania szkód przez te gatunki zwierząt, za które Skarb Państwa nie odpowiada na zasadach określonych w ustawie Prawo łowieckie bądź w ustawie o ochronie przyrody, w tym przede wszystkim w zakresie szkód rybackich wyrządzonych przez gatunki chronione, takie jak kormoran, czapla siwa, perkoz, wydra czy żuraw ${ }^{13}$, ale tak-

10 K. Kaniecki, Bobry niszcza drzewa nad rzeka Warta, 10 lipca 2013 roku, http://sieradz.naszemiasto.pl/artykul/galeria/1927607,bobry-niszczadrzewa-nad-rzeka-warta-zdjecia,id,t.html.

11 Rolnictwo Kujaw i Pomorza, GazetaPomorska.pl, Dzikie zwierzęta stołują się na polach, 30 stycznia 2013 roku, http://www.pomorska.pl/apps/pbcs. dll/article?AID=/20130130/ROLNICTWO01/130139999.

12 Krajowa Rada Izb Rolniczych, Obowiazkowe ubezpieczenie upraw od szkód powodowanych przez zwierzynę łowna, 10 listopada 2011 roku, http:// krir.pl/index.php?option $=$ com_content\&task $=$ view\&id $=1593 \&$ Itemid $=1$.

13 M. Zuba, interpelacja poselska $\mathrm{nr} 7527 \mathrm{z}$ dnia 7 sierpnia 2012 roku w sprawie zagrożenia bankructwem polskich hodowców ryb słodkowodnych oraz postępujących w ślad za tym likwidowaniem polskich stawów hodowlanych na skutek uniemożliwienia hodowcom odstrzału i płoszenia ptaków i wydr pasożytujących na hodowlach. Odpowiedzi udzielono w dniu 28 sierpnia 2012 roku. http://www.sejm.gov.pl/sejm7.nsf/interpelacja.xsp?ty$\mathrm{p}=\mathrm{INT \& nr}=7527$. Komisja Ochrony Środowiska, Zasobów Naturalnych i Leśnictwa, zapis przebiegu posiedzenia (nr 17) z dnia 12 kwietnia 2012 roku rozpatrzenie informacji Ministra Środowiska nt. szkód powodowanych przez 
że w zakresie szkód wyrządzonych przez dzikie gęsi w oziminach ${ }^{14}$, czy szkód wyrządzonych przez zające (będące zwierzyną łowną) w sadach owocowych ${ }^{15}$. Odpowiadając na kierowane zapytania poselskie, przedstawiciele Ministerstwa Środowiska powołują się najczęściej na argument ekonomiczny związany z koniecznością ponoszenia przez Skarb Państwa znaczących nakładów finansowych, które wzrosłyby kilkukrotnie, w tym również o koszty związane z prowadzeniem postępowań likwidacyjnych, ale także na trudności związane z szacowaniem szkód. Wielokrotnie podnoszonym przez Ministerstwo argumentem mającym świadczyć o tym, że aktualne rozwiązania prawne są wystarczające, była również okoliczność, jakoby szkody wyrządzone przez inne zwierzęta, czyli szkody nieobjęte reżimem odpowiedzialności w opisywanych powyżej trybach ustawowych, miały charakter marginalny. Tymczasem, podczas gdy łączna kwota odszkodowań wypłaconych w 2011 roku zgodnie z przepisami ustawy Prawo łowieckie i ustawy o ochronie przyrody za szkody wyrządzone przez zwierzynę łowną wyniosła blisko 60 milionów złotych, a przez zwierzynę objętą ochroną gatunkową wyniosła ponad 11 milionów złotych, szkody wyrządzone tylko w stawach karpiowych przez pozostałą zwierzynę objętą ochroną gatunkową wyniosły w 2011 roku aż 127 milionów złotych, a więc nieporównywalnie więcej ${ }^{16}$.

Zastrzeżenia dotyczące regulacji odpowiedzialności za szkody wyrządzone przez zwierzynę wolno żyjącą od wielu lat przedstawia również Rzecznik Praw Obywatelskich. Wielokrotnie kwestionował on zawarte w Prawie łowieckim i w ustawie

zwierzęta objęte ochroną gatunkową, http://orka.sejm.gov.pl/Zapisy7. nsf/0/1F7EDE97C363022CC12579EB0049D8F6/\$file/0044507.pdf

14 I. Kloc, interpelacja poselska nr 2060 z dnia 25 lutego 2008 roku. Odpowiedzi udzielono w dniu 14 kwietnia 2008 roku. http://orka2.sejm.gov.pl/ IZ6.nsf/main/731C6B49.

15 P. Polak, interpelacja poselska nr 7330 z dnia 23 czerwca 2010 roku w sprawie szkód łowieckich wyrządzonych przez zające w gospodarstwie rolnym, w tym w sadzie owocowym. Odpowiedzi udzielono w dniu 16 lipca 2010 roku. http://orka2.sejm.gov.pl/IZ6.nsf/main/19356393.

16 Komisja Rolnictwa i Rozwoju Wsi, zapis przebiegu posiedzenia (nr 84) z dnia 6 lutego 2013 roku, http://orka.sejm.gov.pl/zapisy7.nsf/0/56DD2A9F9D5E868DC1257B12004F650E/\%24File/0146207.pdf. 
o ochronie przyrody ograniczenie liczby gatunków zwierząt, za które odpowiedzialność ponosi Skarb Państwa ${ }^{17}$, ale również podawał w wątpliwość zasadność uzależniania przyznania odszkodowania od wysokości szkody ${ }^{18}$.

Liczba postulatów dotyczących zmiany zasad odpowiedzialności odszkodowawczej za szkody wyrządzone przez zwierzęta dzikie, a także ich szeroki zakres wskazują jednoznacznie, że kwestia ta budzi wiele wątpliwości i zastrzeżeń.

Jedno z takich zagadnień stanowiło przedmiot postępowania przed Sądem Rejonowym w Pile, w której to sprawie doszło do zalania działki rekreacyjnej stanowiącej własność powoda. Ustalono, że szkoda ta została wyrządzona przez bobry. Zgodnie z literalnym brzmieniem art. 126 ustawy o ochronie przyrody Skarb Państwa nie ponosiłby w tej sprawie odpowiedzialności ponieważ szkoda nie powstała w gospodarstwie rolnym, leśnym bądź rybackim. Sąd Rejonowy powziął jednak wątpliwość, czy różnicowanie sytuacji poszkodowanego właściciela gruntu rekreacyjnego z sytuacją poszkodowanych właścicieli

17 Rzecznik Praw Obywatelskich, wystąpienie z dnia 12 maja 2009 roku, RPO-612357-X/2009/PM dotyczące m.in. ograniczenia w prawie łowieckim odpowiedzialności szkód wyrządzonych tylko przez niektóre gatunki zwierząt. http://www.sprawy-generalne.brpo.gov.pl/pdf/2009/03/612357/1390338. pdf. Rzecznik Praw Obywatelskich, wystąpienie z dnia 3 grudnia 2010 roku, RPO-643913-X/2010/PM wskazujące, że również pozostałe zwierzęta objęte ścisłą ochrona gatunkową powodują istotne szkody w majątku trwałym, hodowlach i uprawach. http://www.sprawy-generalne.brpo.gov.pl/szczegoly.php?pismo = 1531662. Rzecznik Praw Obywatelskich, wystąpienie z dnia 21 września 2000 roku, nr 34748, RPO/285007/98/X/KMS dotyczące braku norm określających zasad odpowiedzialności Skarbu Państwa w zakresie szkód wyrządzanych w uprawach przez żurawie i przez ptaki z rodziny drozdów, które wyrządzają szkody w sadach. http://www.sprawy-generalne. brpo.gov.pl/szczegoly.php?pismo $=587709$. Rzecznik Praw Obywatelskich, wystąpienie z dnia 25 lipca 2006 roku, nr RPO-533573-X/06/PM dotyczące skarg rolników na brak możliwości dochodzenia odszkodowań z tytułu szkód łowieckich wyrządzonych przez zające w sadach. http://www.sprawy-generalne.brpo.gov.pl/szczegoly.php?pismo $=1137440$.

18 Rzecznik Praw Obywatelskich, wystąpienie $\mathrm{z}$ dnia 31 sierpnia 2000 roku, RPO/343712/2000/X/KMS m.in. w sprawie uzależniania przyznania odszkodowania za szkody wyrządzone przez dziki od wartości szkody. http://www.sprawy-generalne.brpo.gov.pl/szczegoly.php?pismo $=583188$. 
gospodarstw rolnych, leśnych i rybackich jest zgodne z konstytucyjnymi zasadami równości i prawnej ochrony własności i skierował do Trybunału Konstytucyjnego zapytanie w tym przedmiocie. W toku postępowania przed Trybunałem Konstytucyjnym swoje stanowisko przedstawił Prokurator Generalny ${ }^{19}$ oraz Marszałek Sejmu ${ }^{20}$. W ich ocenie istniejące zróżnicowanie podmiotów poszkodowanych według kryterium przedmiotowego, jakim jest wyrządzenie szkody przez bobry w gospodarstwie określonego typu, nie spełnia konstytucyjnych wymogów zasady równości. Podobnie Konstytucja nie różnicuje ochrony prawa własności w zależności od rodzaju własności. Sędziowie Trybunału Konstytucyjnego zwrócili się także do Ministra Środowiska o wskazanie zakresu szkód wyrządzanych przez bobry

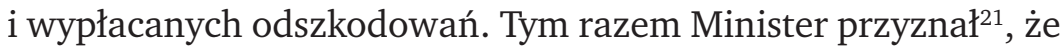
brak objęcia odpowiedzialnością z art. 126 ustawy o ochronie przyrody szkód innych, niż wyrządzone w gospodarstwie rolnym, leśnym lub rybackim, stanowi dyskryminację właścicieli innych nieruchomości.

W dniu 3 lipca 2013 roku Trybunał Konstytucyjny orzekł ${ }^{22}$, że art. 126 ust. 1 pkt 5 ustawy o ochronie przyrody jest niezgodny z art. 32 i art. 64 ust. 2 Konstytucji w zakresie, w jakim ogranicza odpowiedzialność Skarbu Państwa za szkody wyrządzone przez bobry wyłącznie do szkód powstałych w gospodarstwie

19 Prokurator Generalny Rzeczypospolitej Polskiej, stanowisko z dnia 9 stycznia 2012 roku, PG VIII TK 83/11 (P49/11). http://db.trybunal. gov.pl/sprawa/sprawa_pobierz_plik62.asp?plik=F315125219/P_49_11_ PG_2012_01_09_ADO.pdf\&syg $=$ P\%2049/11.

20 Marszałek Sejmu Rzeczypospolitej Polskiej, stanowisko z dnia 7 listopada 2011 roku, BAS-WPTK-2072/11. http://db.trybunal.gov.pl/sprawa/sprawa_pobierz_plik62.asp?plik=F1871518306/P_49_11_Sjm_2011_11_07_ ADO.pdf\&syg =P\%2049/11.

21 Minister Środowiska, pismo z dnia 12 marca 2013 roku, DLPnat-073-31/9915/13/RS. http://db.trybunal.gov.pl/sprawa/sprawa_pobierz_plik62.asp?plik=F414269811/P_49_11_ms_2013_03_12_ADO. pdf\&syg $=\mathrm{P} \% 2049 / 11$.

22 Wyrok Trybunału Konstytucyjnego z dnia 3 lipca 2013 roku, sygn. akt P 49/11, nr 73/6/A/2013, Dz.U. poz. 842. http://isap.sejm.gov.pl/DetailsServlet?id=WDU20130000842. 
rolnym, leśnym lub rybackim. W komunikacie prasowym ${ }^{23}$ wydanym po rozprawie podano, że art. 126 ust.1 pkt 5 ustawy o ochronie przyrody różnicuje sytuację podmiotów, które poniosły taką szkodę w zależności od tego, w jakim dobru szkoda została wyrządzona. Takie różnicowanie nie pozostaje w związku z wartościami, zasadami i normami konstytucyjnymi uzasadniającymi odmienne traktowanie podmiotów podobnych, a co więcej, przenosi to koszty funkcjonowania ochrony gatunkowej zwierząt na te podmioty. Zauważono także, że w sytuacji, gdy ustawodawca przyznaje ustawą prawo do odszkodowania jednym podmiotom, musi jednocześnie respektować zasadę równości wobec prawa (art. 32 ust. 1 Konstytucji) oraz zasadę równej ochrony prawnej własności i innych praw majątkowych (art. 64 ust. 2 Konstytucji).

W konsekwencji wskazanego orzeczenia Prokurator Generalny złożył 31 lipca 2013 roku wniosek ${ }^{24}$ do Trybunału Konstytucyjnego o stwierdzenie niezgodności przepisu art. 126 ust.1 pkt $1-4$ z art. 32 ust. 1 i art. 64 ust. 2 Konstytucji, w zakresie, w jakim ogranicza on odpowiedzialność Skarbu Państwa jedynie do szkód wyrządzonych przez żubry, wilki, rysie i niedźwiedzie w konkretnie wskazanym w tym przepisie mieniu. W uzasadnieniu złożonego wniosku Prokurator Generalny przytoczył argumentację leżącą u podstaw wydania przez Trybunał Konstytucyjny wyroku z dnia 3 lipca 2013 roku i podniósł, że różnicowanie sytuacji prawnej podmiotów prawa musi pozostawać $\mathrm{w}$ racjonalnym związku z celem i treścią danej regulacji i musi być racjonalnie uzasadnione. Nadto, argumenty przemawiające za odmiennym ukształtowaniem sytuacji prawnej podmiotów muszą pozostawać w odpowiedniej proporcji do wagi interesów, które zostaną naruszone, oraz muszą pozostawać w związku z innymi konstytucyjnymi zasadami i wartościami. Prokurator

23 Trybunał Konstytucyjny, komunikat prasowy dotyczący wyroku z dnia 3 lipca 2013 roku, sygn. akt P 49/11 w sprawie odpowiedzialności Skarbu Państwa za szkody wyrządzone przez bobry. http://www.trybunal.gov.pl/Rozprawy/2013/rozprawy.htm.

24 Prokurator Generalny Rzeczypospolitej Polskiej, wniosek z dnia 30 lipca 2013 roku, PG TKw 42/13. http://www.pg.gov.pl/upload_doc/000004048. pdf. 
Generalny wskazał na wynikającą z art. 64 Konstytucji zasadę ochrony prawa własności i fakt, że prawa majątkowe podlegają równej dla wszystkich ochronie prawnej, co oznacza, że ochrona ta nie może być różnicowana $\mathrm{z}$ uwagi na zakres podmiotowy. Skoro zatem ustawodawca ustanowił szczególne zasady odpowiedzialności za szkody wyrządzone przez wybrane zwierzęta danej grupie podmiotów, to powinien był jednocześnie respektować konstytucyjną zasadę równości wobec prawa dla wszystkich i równej ochrony prawnej własności i innych praw majątkowych. Podobnie, w ocenie Prokuratora Generalnego, za nieuzasadnione należy uznać zawężenie przedmiotowe odpowiedzialności odszkodowawczej do wskazanych rodzajów dóbr, w których nastąpi szkoda. Z tych przyczyn uzależnianie przyznania odszkodowania od tego, w jakim mieniu żubry, wilki, rysie i niedźwiedzie wyrządzą szkodę, jest nieuzasadnione. Przedmiotowy wniosek oczekuje obecnie na rozpoznanie przez Trybunał Konstytucyjny.

W tym miejscu należy jednak zwrócić uwagę, że zmiana całego ust. 1 art. 126 ustawy o ochronie przyrody, w zakresie, w jakim uzależnia przyznanie odszkodowania od rodzaju mienia, w jakim wskazane $\mathrm{w}$ nim zwierzęta wyrządzą szkodę, nie wyczerpuje kompleksowo problematyki odpowiedzialności za szkody wyrządzone przez zwierzęta wolno żyjące i istniejących na tym tle wątpliwości.

Przede wszystkim należy zwrócić uwagę na to, że przepisy ustawy Prawo łowieckie także uzależniają przyznanie odszkodowania od rodzaju mienia, w którym zwierzyna łowna wyrządziła szkodę. Dzierżawca lub zarządca obwodu łowieckiego lub Skarb Państwa będą bowiem ponosić odpowiedzialność jedynie wówczas, gdy szkoda wystąpiła w uprawach i płodach rolnych.

W dalszym ciągu brak jest również regulacji w zakresie odpowiedzialności odszkodowawczej za szkody wyrządzane przez te gatunki zwierzyny łownej, które nie zostały wymienione $\mathrm{w}$ art. 46 ust. 1 i art. 50 ustawy Prawo łowieckie (np. zające), a co do których prowadzona jest gospodarka łowiecka. Czy wobec bardziej rygorystycznego trybu dochodzenia roszczeń na mocy przepisów Kodeksu cywilnego, przewidzianego dla tego 
rodzaju szkód, poszkodowani przez takie zwierzęta nie są dyskryminowani?

Podobnie, czy kierując się potrzebą utrzymania ochrony gatunkowej zwierząt zagrożonych wyginięciem i wyrządzających szkody w gospodarce człowieka, Skarb Państwa nie powinien odpowiadać za szkody wyrządzone przez zwierzęta chronione inne niż łoś, żubr, wilk, ryś, niedźwiedź i bóbr? Podkreślenia przy tym wymaga, że szkody wyrządzane przez chronione gatunkowo ptaki rybożerne w stawach hodowlanych przybierają znaczące rozmiary, a rekompensata poniesionych strat niewątpliwie zwiększyłaby tę ochronę, niwelując konflikt pomiędzy interesem ekonomicznym poszkodowanej jednostki, a interesem publicznym, polegającym na zachowaniu chronionego gatunku zwierząt.

Wreszcie, czy w zgodzie z przywołanymi zasadami konstytucyjnymi pozostają przepisy art. 48 pkt 4 ustawy Prawo łowieckie oraz art. 126 ust. 6 pkt 3b ustawy o ochronie przyrody uzależniające uzyskanie odszkodowania od wartości doznanej szkody? Zapis ten powoduje, że grupa osób dotkniętych szkodami mniejszego rozmiaru ponosi koszty strat wyrządzonych przez zwierzęta, wobec których prowadzona jest gospodarka łowiecka lub sprawowana jest ochrona gatunkowa.

\section{NIEKTÓRE UWAGI „DE LEGE FERENDA”}

Mając na uwadze znaczenie omawianych zagadnień, udzielenie odpowiedzi na zadane na wstępie pytania powinno być zagadnieniem istotnym nie tylko dla poszkodowanych ze strony zwierząt wolno żyjących, dla zobowiązanych do naprawiania tych szkód oraz dla podmiotów realizujących politykę państwa w zakresie ochrony przyrody, lecz przede wszystkim dla organów władzy państwowej.

W świetle wydanego w dniu 3 lipca 2013 roku wyroku Trybunału Konstytucyjnego konieczne staje się poddanie kontroli wymienionych powyżej przepisów ustawy Prawo łowieckie i ustawy o ochronie przyrody pod kątem ich zgodności z Konsty- 
tucją. Zasadne wydaje się, aby przedmiotowej analizie poddane zostały zarówno regulacje różnicujące zasady odpowiedzialności odszkodowawczej ze względu na rodzaj mienia, w jakim wyrządzona została szkoda, lecz także regulacje uzależniające wypłatę odszkodowania od rozmiaru szkody. Na szczególną uwagę zasługują również zapisy ustanawiające odpowiedzialność za szkody wyrządzone przez jedynie niektóre ze zwierząt łownych i zwierząt objętych ochroną gatunkową i kryteria, wedle których ustawodawca dokonuje przedmiotowego wyboru.

Należy bowiem rozważyć, czy istniejące różnicowanie sytuacji prawnej podmiotów poszkodowanych rzeczywiście pozostaje $\mathrm{w}$ racjonalnym związku z celem i treścią wspomnianych ustaw i pozostaje w odpowiedniej proporcji do wagi interesów, które zostaną naruszone w wyniku takiego zróżnicowania. Nie bez znaczenia pozostaje również fakt, że różnicowanie sytuacji prawnej niektórych podmiotów musi być zgodne z zasadą równości wobec prawa i równej ochrony prawnej własności oraz z zasadą sprawiedliwości społecznej.

Zasadne wydaje się stworzenie takich regulacji prawnych, które tym razem kompleksowo, w spójny i czytelny sposób rozwiązywałyby pojawiające się sporne zagadnienia na tle odpowiedzialności za szkody wyrządzone przez stanowiące dobro ogólnonarodowe zwierzęta dzikie, zarówno z punktu widzenia interesu poszkodowanych obywateli, jak i ochrony środowiska. Stwierdzenie przez Trybunał Konstytucyjny, że niezgodne z obowiązującym porządkiem prawnym jest uzależnienie przyznania odszkodowania w trybie ustawy o ochronie przyrody od rodzaju mienia, w jakim została ona wyrządzona, powinno stanowić niezbędny impuls do podjęcia niezbędnych działań w tym zakresie.

\section{BIBLIOGRAFIA}

Goettel M., Sytuacja prawna zwierzęcia $w$ prawie cywilnym, Warszawa 2013, s. 437.

Kaniecki K., Bobry niszcza drzewa nad rzeką Warta, 10 lipca 2013 roku. http://sieradz.naszemiasto.pl/artykul/galeria/1927607, bobryniszcza-drzewa-nad-rzeka-warta-zdjecia,id,t.html. 
Kloc I., interpelacja poselska nr 2060 z dnia 25 lutego 2008 roku. http://orka2.sejm.gov.pl/IZ6.nsf/main/731C6B49.

Komisja Ochrony Środowiska, Zasobów Naturalnych i Leśnictwa, zapis przebiegu posiedzenia (nr 17) z dnia 12 kwietnia 2012 roku rozpatrzenie informacji Ministra Środowiska nt. szkód powodowanych przez zwierzęta objęte ochroną gatunkową. http://orka.sejm.gov.pl/Zapisy7.nsf/0/1F7EDE97C363022CC12579EB0049D8F6/\$file/0044507.pdf.

Krajowa Rada Izb Rolniczych, Obowiązkowe ubezpieczenie upraw od szkód powodowanychprzez zwierzynę łowna, 10 listopada 2011 roku. http://krir.pl/index.php?option=com_content\&ta$\mathrm{sk}=$ view\&id $=1593 \&$ Itemid $=1$.

Marszałek Sejmu Rzeczypospolitej Polskiej, stanowisko z dnia 7 listopada 2011 roku, BAS-WPTK-2072/11. http://db.trybunal.gov.pl/sprawa/sprawa pobierz_plik62.asp?pli$\mathrm{k}=\mathrm{F} 1871518306 / \mathrm{P} \_49$ _11_Sjm_2011_11_07_ADO.pdf\&sy$\mathrm{g}=\mathrm{P} \% 2049 / 11$.

Minister Środowiska, pismo z dnia 12 marca 2013 roku, DLPnat-073-31/9915/13/RS. http://db.trybunal.gov.pl/sprawa/ sprawa_pobierz_plik62.asp?plik=F414269811/P_49_11_ ms 20130312 ADO.pdf\&syg=P\%2049/11.

Polak P., interpelacja poselska nr 7330 z dnia 23 czerwca 2010 roku w sprawie szkód łowieckich wyrządzonych przez zające w gospodarstwie rolnym, w tym w sadzie owocowym. http://orka2. sejm.gov.pl/IZ6.nsf/main/19356393.

Prokurator Generalny Rzeczypospolitej Polskiej: Stanowisko z dnia 9 stycznia 2012 roku, PG VIII TK 83/11 (P 49/11). http:// db.trybunal.gov.pl/sprawa/sprawa_pobierz_plik62.asp?pli$\mathrm{k}=\mathrm{F} 315125219 / \mathrm{P}$ 49_11_PG_2012_01_09_ADO.pdf\&sy$\mathrm{g}=\mathrm{P} \% 2049 / 11$.

Wniosek z dnia 30 lipca 2013 roku, PG TK w 42/13. http://www. pg.gov.pl/upload_doc/000004048.pdf.

Radecki W., Prawo łowieckie. Komentarz, Warszawa 2012, s. 288.

Rolnictwo Kujaw i Pomorza, GazetaPomorska.pl, Dzikie zwierzęta stołuja się na polach, 30 stycznia 2013 roku, http://www.pomorska.pl/apps/pbcs.dll/article?AID =/20130130/ROLNICTWO01/130139999.

Rzecznik Praw Obywatelskich: Wystąpienie z dnia 12 maja 2009 roku, RPO-612357-X/2009/PM dotyczące m.in. ograniczenia w prawie łowieckim odpowiedzialności szkód wyrządzonych tylko przez niektóre gatunki zwierząt. http://www.sprawygeneralne. brpo.gov.pl/pdf/2009/03/612357/1390338.pdf. 
Wystąpienie z dnia 3 grudnia 2010 roku, RPO-643913-X/2010/PM wskazujące, że również pozostałe zwierzęta objęte ścisłą ochroną gatunkową powodują istotne szkody w majątku trwałym, hodowlach i uprawach. http://www.sprawygeneralne.brpo.gov.pl/ szczegoly.php?pismo $=1531662$.

Wystąpienie z dnia 21 września 2000 roku, nr 34748, RPO/285007/98/X/KMS dotyczące braku norm określających zasad odpowiedzialności Skarbu Państwa w zakresie szkód wyrządzanych w uprawach przez żurawie i przez ptaki z rodziny drozdów, które wyrządzają szkody w sadach. http://www.sprawy-generalne.brpo.gov.pl/szczegoly.php?pismo $=587709$.

Wystąpienie z dnia 25 lipca 2006 roku, nr RPO-533573-X/06/PM dotyczące skarg rolników na brak możliwości dochodzenia odszkodowań z tytułu szkód łowieckich wyrządzonych przez zające w sadach. http://www.sprawygeneralne.brpo.gov.pl/szczegoly. php?pismo $=1137440$.

Wystąpienie z dnia 31 sierpnia 2000 roku, RPO/343712/2000/X/KMS m.in. w sprawie uzależniania przyznania odszkodowania za szkody wyrządzone przez dziki od wartości szkody. http://www. sprawy-generalne.brpo.gov.pl/szczegoly.php?pismo $=583188$.

Zachodniopomorska Izba Rolnicza, Szkody towieckie - narastajacy problemzachodniopomorskich rolników, 5 kwietnia 2013 roku, http://www.archiwum2.zir.pl/index.php/210-szkodylowieckie-narastajacy-problem-zachodniopomorskich-rolnikow.

Zuba M., interpelacja poselska nr 7527 z dnia 7 sierpnia 2012 roku w sprawie zagrożenia bankructwem polskich hodowców ryb słodkowodnych oraz postępujących w ślad za tym likwidowaniem polskich stawów hodowlanych na skutek uniemożliwienia hodowcom odstrzału i płoszenia ptaków i wydr pasożytujących na hodowlach. http://www.sejm.gov.pl/sejm7.nsf/interpelacja. $\mathrm{xsp}$ ?typ $=\mathrm{INT} \& \mathrm{nr}=7527$.

Kontakt e-mail:

kamila.piernik@gmail.com 